\title{
Heavy Infestation of Sugracane Pyrilla in Rice, Probable Reason of Spread and its Control in the State of J \& K, India
}

\author{
Rupinder Singh ${ }^{1 *}$ and Ravishankar Narayana ${ }^{2}$ \\ ${ }^{1}$ Department of Agriculture, Government of $J \& K$, India \\ ${ }^{2}$ CIDD, Dept of Entomology \& Biology, Penn State University, USA
}

Submission: February 08, 2017; Published: February 27, 2017

*Corresponding author: Rupinder Singh, Department of Agriculture, Government of J \& K, India, E.mail: roop0071@yahoo.com

\begin{abstract}
Pyrilla perpusilla (Walker), although the pest of sugarcane rarely infest the crop of paddy. Very few reports of attack of sugarcane pyrilla in rice have been reported so far. One such incidence reported in the village Bhour pind of district Jammu in Kharif season of 2016 in hybrid variety Poonam. Although it was a localised attack and timely control of the pest limits its further spread to the adjoining area which is predominately a paddy grown area.
\end{abstract}

Key Words: Rice; Paddy; Sugarcane; Pyrilla perpusilla; Plant leafhopper

\section{Introduction}

Both the nymph and adult damage the crop by sucking sap from the foliage there by depriving the plant nutrients (Figure 1), Sugarcane pyrilla or leafhopper Pyrilla perpusilla is a serious pest of sugarcane in northern India, and is potentially dangerous to rice, wheat, maize, bajra, oats, sorghum, particularly the hybrid varieties Pawar [1].

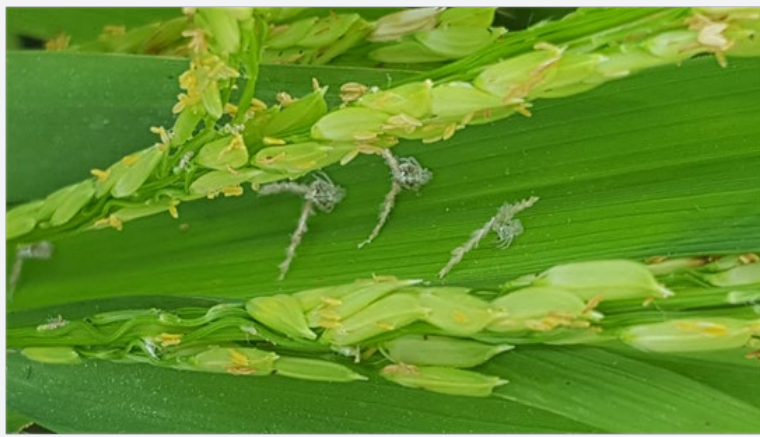

Figure 1: Nymphs of Sugarcane pyrilla attacking paddy crop.

Incidence of Pyrilla perpusilla attacking rice has also been reported in the state of Haryana at Karnal and Sonepat (197879) and in the Gurdaspur district of Punjab as early as 1980 Pawar [1]. Apart from India, it is distributed in Afghanistan,
Bangladesh, Borneo, Burma, Cambodia, Indonesia, Java, Nepal, Laos, Pakistan, South China, Sri Lanka, Sumatra, Thailand and Vietnam Khanzada [2]; Kumarasinghe \& Wratten [3].

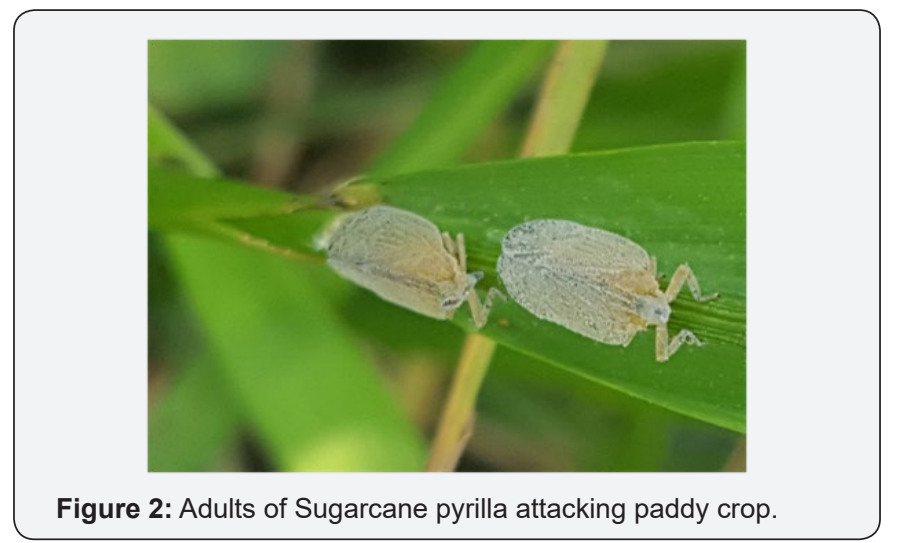

Occasionally, it is also seen in the fields of Okra, Cucurbit vegetables and certain legumes Singh [4]. Both nymphs and adults of the pest suck sap from the leaves of rice (Figure $1 \&$ 2) but most of the damage is caused by the nymphal stage (Figure 1). The adults are white immediately after moulting but gradually turned straw coloured, with pale green eyes, snout-like head with black spot positioned posteriorly. The apical area and the outer cleval wing margins have minute black spots (Figure 
2 \& 3) Singh and Bihari [5]. Females are generally longer than males and have pads bearing bundles of cretaceous filaments at their anal end. Wing expanse for females varies from 19-21 mm and for males 16-18 mm Mishra [6].

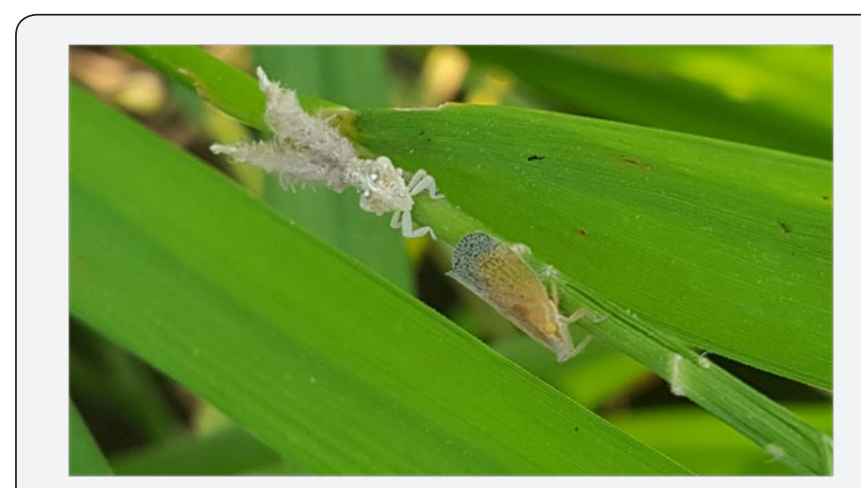

Figure 3: Nymph and Adult of Sugarcane pyrilla attacking paddy crop.

\section{Materials and Methods}

In the present study two rice varieties, Poonam which is a hybrid and a traditional Sharbati basmati rice were evaluated in the field of 506 sqm (1Kanal or $1 / 8$ acre) each during the kharif season of 2016. First a Neem based bio-pesticide 'Neem Baan' containing $0.15 \%$ Azadirachtin was used which was followed by another insecticide after three days. In the later, Chloropyriphos $50 \%+$ Cypermethrin 5\% EC was applied to avoid further spread of this deadly pest. In both the fields recommended agronomic practices were used. On the bund of both the fields' sugarcane crop was also grown in isolated pockets.

\section{Results and Discussion}

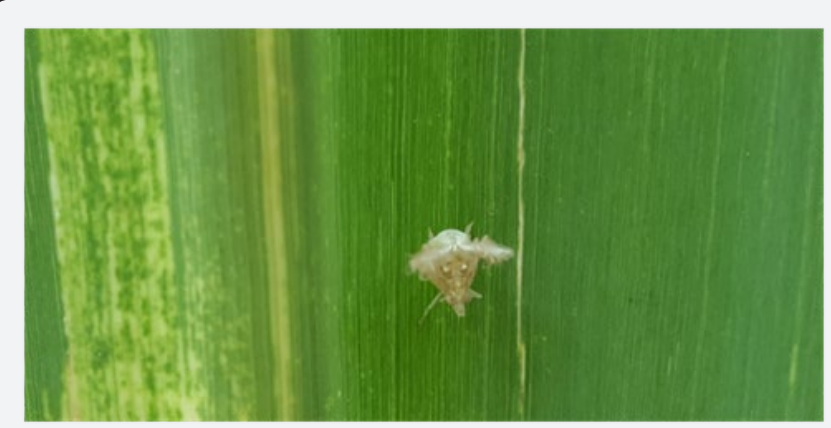

Figure 4: Sugarcane pyrilla attacking Sugarcane crop grown on the bunds of paddy field.

Heavy infestation of sugarcane pyrilla was observed in the hybrid variety poonam which was found to be quite susceptible towards Pyrilla perpusilla. Such incidence of attack of Pyrilla perpusilla particularly on hybrids was also reported by Pawar [1]. Although very less incidence was seen in traditional Sharbati basmati rice and that can be categorised as negligible. Therefore it seems to be predominately a resistant variety towards Pyrilla perpusilla. No such incidence of attack of Pyrilla perpusilla has been reported earlier in this state and hence careful observations were made to identify the basic cause behind the heavy infestation in the variety poonam. Sugarcane grown on the bunds of the fields of both the varieties had actually inhabited Sugarcane pyrilla (Figure 4) which spread it to the paddy field when the paddy crop was at flowering stage. Such migration of Pyrilla perpusilla from sugarcane to paddy has also been reported by Pawar [1].

Heavy use of nitrogenous fertilizer in hybrid variety facilitates the higher rate of infestation of Sugarcane Pyrilla as in the case of hybrid variety poonam. Pyrilla perpusilla can be effectively controlled by ectoparasite Epipyrops melanoleuca and it can be released in Pyrilla-infested fields at 40,000-50,000 eggs/Ha when the Pyrilla population averages 3.5 individuals (eggs+nymphs+adults/leaf) Pawar [1].

The results of both the above mentioned pesticides were evaluated and neem based bio-pesticide couldn't be able to control the spread of the Pyrilla perpusilla in a time bond manner and $100 \%$ control was achieved by Chloropyriphos $50 \%+$ Cypermethrin 5\% EC within 48hrs of its use.

There is not much study on the development of tolerant/ resistant varieties particularly in rice against Sugarcane Pyrilla. Antibiosis tests had been carried out with first and third instar nymphs of Pyrilla perpusilla in Sugarcane Kumarasinghe \& Wratten [7]; and the antixenotic effects of foliar morphological and and chemical characteristics of sucking pest of Sugarcane Pyrilla perpusilla was also been studied by Kumarasinghe \& Jepson [8]. Antibiosis and antixenosis tests in paddy could also pave the way for the development of tolerant/resistant varieties against Pyrilla perpusilla.

\section{Reference}

1. Pawar AD (1981) Sugarcane pyrilla attacking rice, and the biological control in India. Int Rice Res. NewsL 6(3): 17.

2. Khanzada AG (1992) A comprehensive review of research work on sugarcane leaf hopper, Pyrilla perpusilla Wlk. J Agric Res 30(2): 271282.

3. Kumarasingha NC, Wratten SD (1996) The sugarcane liphopid planthopper Pyrilla perpusilla (Homoptera: Lophopidae): a review of its biology, pest status and control. Bull Entomol Res 86(5): 485-498.

4. Singh R (2006) Elements of Entomology, A text book for university students. Rastogi Pub, India, p. 337.

5. Singh R, Singh BB (2014) Major Rice Insect Pests in Northeastern U.P. Int J Life Sc Bt \& Pharm Res 3(1): 132.

6. Mishra SR (2005) A text book of plant protection and pest management. Discovery Pub House, New Delhi, India, p. 137.

7. Kumarasinghe NC, Wratten SD (1993) Host plant resistance in sugarcane (Saccharam officinarum) to the lophopid plant hopper Pyrilla perpusilla (Hom; Lophopidae). Bulletin OILC/SROP 16 (5): 144154.

8. Kumarasinghe NC, Jepson PC (2003) Antixenotic effects of sugarcane leaves on feeding and oviposition by Pyrilla perpusilla Walker. Sugar Tech 5: 11-19. 
This work is licensed under Creative Commons Attribution 4.0 License

DOI: 10.19080/ARTOAJ.2017.04.555635

\section{Your next submission with Juniper Publishers will reach you the below assets}

- Quality Editorial service

- Swift Peer Review

- Reprints availability

- E-prints Service

- Manuscript Podcast for convenient understanding

- Global attainment for your research

- Manuscript accessibility in different formats ( Pdf, E-pub, Full Text, Audio)

- Unceasing customer service

Track the below URL for one-step submission https://juniperpublishers.com/online-submission.php 